Archiv für die gesamte Virusforschung 44, 35-50 (1974)

(C) by Springer-Verlag 1974

\title{
Characteristies of a Coronavirus Causing Vomition and Wasting in Pigs
}

\author{
By \\ M. B. Pensaert and P. E. Callebaut \\ Laboratory of Virology, Faculty of Veterinary Medicine, University of Ghent \\ Ghent, Belgium \\ With 5 Figures
}

Received September 7, 1973

\section{Summary}

Some characteristics of a virus, isolated from the tonsils of 2 pigs with clinical signs of inappetence and vomition and designated VW 572 were examined. It induced the formation of syncytia in primary pig kidney cell cultures, caused hemadsorption and hemagglutination using chicken, turkey, rat and mouse erythrocytes. In growth curve experiments, infectious virus was produced intracellularly starting at 6 hours after inoculation and was followed by rapid release of the virus from the infected cells. The virus contains ribonucleic acid, is ether sensitive and has a size between 100 and $220 \mathrm{~nm}$. At $37^{\circ} \mathrm{C}$, the infectivity titer decreased about $2 \log _{10} \mathrm{TCID}_{50}$ per 24 hours. The viral population was heterogeneous as indicated by the rate of inactivation by U.V. irradiation and acid $\mathrm{pH}$. Some hemagglutinating activity was left after complete loss of infectivity by ether-, temperature- and U.V. treatment. The VW 572 isolate is antigenically related if not identical to isolates from Canada, U.S.A. and England which were classified as a porcine coronavirus.

Oronasal and intracerebral inoculation of the VW572 isolate in colostrum deprived pigs resulted in clinical disease after an incubation period of 6 and 4 days, respectively. Signs were characterized by depression, vomition, loss of appetence with rapid weakness in young pigs and vomition with progressive wasting in older pigs. Virus was isolated from nasal and pharyngeal swabs, nasal mucosa, tonsils, lungs and hind brains but not from rectal swabs or other organs tested. Virus could not be isolated later than 8 days after inoculation. Hemagglutination inhibiting and neutralizing antibodies were detected in sera at 6 days and 9 days after inoculation, respectively.

\section{Introduction}

Starting in 1968, a previously unrecognized disease in pigs was observed in several European countries $(5,10,31)$. Clinical symptoms were seen only in pigs and were characterized by frequent vomition, decreased appetence, gradual loss of condition and high mortality. Although several possible causes were set forward, CARTWRIGHT et al. (5) soon isolated a hemagglutinating virus from pigs affected 
by this "vomiting and wasting disease". The results of the examination of some properties of the British virus isolate led to earlier studies carried out in Canada by GREIG et al. (11). In this work, the isolation of a similar hemagglutinating virus from pigs with hemagglutinating encephalitis, a central nervous disorder, was reported. Antigenic relationship was found to exist between the Canadian and the British isolates $(5,6)$.

Recently, MENGELING et al. (22) reported on the characteristics of a coronavirus isolated from the nasal cavity of a healthy feeder pig. The isolate was found. to be antigenically related to the hemagglutinating encephalitis virus from Canada. Although no outbreaks of hemagglutinating encephalitis had been recognized in the U.S.A., this virus was proven to be pathogenic for pigs.

Numerous natural outbreaks of vomiting and wasting disease have occurred in Belgium during the last 3 to 4 years. Obvious central nervous disorders characterized by incoordination, ataxia and paralysis as described in Canada have, however, not been observed. From several affected pigs, a virus was isolated.

It was the purpose of the present study to examine some biological and physicochemical characteristics of one of the Belgian isolates, designated VW 572, in order to determine its similarities or differences with isolates from other countries. Because some differences appear to exist in pathogenic properties, the results of the experimental infection of colostrum-deprived pigs with the present isolate are also reported.

\section{Materials and Methods}

\subsection{Cell Cultures}

Primary pig kidney (PPK) cell cultures were used throughout the present study for preparation of virus stocks, for virus isolation from pigs and for serum neutralization tests. A cell line, PK 15, was used for infectivity titrations during the virus characterization experiments.

Stationary cultures of PPK cells were prepared from kidneys, obtained from 4 week old pigs, according to standard procedures (21). Cells were planted in Hanks' lactalbumin medium (HLA) consisting of Hanks' balanced salt solution (BSS), with 0.5 per cent lactalbumin hydrolysate (LAH), and 10 per cent calf serum (CS). After 2 days, the HLA medium was replaced by minimum essential Eagle's medium (MEM), containing 10 per cent CS. After inoculation, cells were maintained using the same medium with 4 per cent foetal calf serum (FCS).

PK 15 cells were grown out in MEM containing 10 per cent CS, 2 per cent LAH and 1 per cent yeast extract; maintenance medium consisted of MEM with 3 per cent FCS, 2 per cent LAH and 1 per cent yeast extract.

\subsection{Virus, Virus Stocks and Infectivity Titrations}

A virus was isolated from the tonsils of two diseased pigs obtained from a litter in which an outbreak of vomiting and wasting (hemagglutinating encephalitis) occurred. The isolate was designated VW 572 and was selected for characterization, identification and pathogenicity studies to be described in the present report.

For virus isolation from the tonsils and from other organs of the experimental pigs, a 20 per cent suspension of the organ was prepared in phosphate buffered saline (PBS) (pH 7.2) by homogenization. After centrifugation at $7500 \times g$, the supernatant fluid was collected and $0.1 \mathrm{ml}$ inoculated in tubes with PPK cells. After 4 days, hemadsorption with chicken erythrocytes was attempted on the monolayer in some tubes, whereas the cells and cell culture medium of other tubes were subjected to freezing and thawing, centrifugation and further inoculation of the supernatant in PPK cells in order to make a following passage. 
Characterization studies with the VW 572 isolate were done at the 14 th to 16 th cell culture passage level in PPK cells. Pathogenicity studies in pigs were performed with the 10th serial passage of the virus.

For preparation of virus stocks, cultures of PPK cells in 2 oz. prescription bottles were used. Two days after inoculation with seed virus, the culture fluids and cells were subjected to two cycles of freezing and thawing, pooled and centrifuged at $2000 \times g$ for 10 minutes. The supernatant fluid was collected and stored at $-70^{\circ} \mathrm{C}$. Infectivity titers usually ranged from $10^{5.0}$ to $10^{6.0}$ median tissue culture infective doses (TCID 50 ) рег $0.1 \mathrm{ml}$.

For infectivity titration of virus containing fluids, tenfold dilutions were prepared in PBS. One-tenth $\mathrm{ml}$ of each dilution was added to each of 4 tubes with cells. The inoculated tubes were incubated at $37^{\circ} \mathrm{C}$ and examined daily for the presence of cytopathic effect (CPE). A final reading was made at the end of 6 days of incubation. In early experiments, the end point was also based on positive or negative hemadsorption in the tubes. The TCID 50 -titer was calculated according to the method of REED and MUENCH (30).

\subsection{Characterization Studies}

\subsubsection{Light Microscopy}

PPK cells were grown on the surface of coverslips in Leighton tubes. Virus infected cultures were stained by the haematoxylin- and eosin (H \& E) method.

\subsubsection{Hemagglutination and Hemadsorption}

Hemadsorption in infected PPK cells and hemagglutinating activity with the VW 572 isolate were tested using erythrocytes of chicken, turkey, rat, mouse, guinea pig, rabbit, goat, sheep and pig. Tests were carried out at $4^{\circ}, 22^{\circ}$ and $37^{\circ} \mathrm{C}$ in order to determine the optimal temperature.

In order to quantitate virus suspensions by hemagglutination titration, $0.5 \mathrm{ml}$ of serial twofold dilutions of virus were mixed with an equal volume of a 0.25 per cent suspension of washed chicken erythrocytes in PBS. The tests were read after 1 hour at $22^{\circ} \mathrm{C}$. Titers were recorded as the reciprocal of the highest dilution showing a distinct pattern of agglutination.

In hemadsorption tests, to be used mainly for virus isolation and for following cellassociated viral growth, $0.2 \mathrm{ml}$ of a 0.5 per cent suspension of chicken erythrocytes in PBS was added to the cell culture medium. After incubating for 30 minutes at $22^{\circ} \mathrm{C}$, the culture medium was discarded and the monolayers were examined for evidence of hemadsorption after washing 2 times with PBS.

\subsubsection{Virus Growth Curve}

PPK culture tubes containing approximately $10^{6}$ cells were inoculated with $10^{6.3}$ TCID $_{50}$ of VW 572 virus. After 1 hour of virus adsorption at $37^{\circ} \mathrm{C}$, tubes were washed 5 times with PBS and fed with maintenance medium. At various time intervals thereafter, the culture medium of 5 tubes, selected at random, was collected, pooled and examined for extra-cellular virus (ECV) by hemagglutination and infectivity titration. The same tubes were washed 5 times with PBS, one $\mathrm{ml}$ of maintenance medium was added and the cells were disrupted by 2 cycles of freezing and thawing. The fluids were pooled and centrifuged for 10 minutes at $2000 \times g$. The supernatant fluid was examined for cell-associated virus (CAV) by hemagglutination and infectivity titration.

At each time interval, 2 tubes were used for hemadsorption in order to follow the spread of virus replication into the monolayer.

\subsubsection{Size Determination}

The size of the VW 572 isolate was estimated by filtrating virus containing culture medium through a series of Millipore membranes with average pore diameters (ADP) of $450,220,100$ and $50 \mathrm{~nm}$. The filters were pretreated with Earle's BSS containing 10 per cent FCS, as described by VER et al. (34). The virus content of the filtrate was determined by infectivity titration and hemagglutination. 


\subsubsection{Type of Nucleic Acid}

PPK cell cultures in 2 oz. prescription bottles were treated with 5-iodo-2'-deoxyuridine (IDU), by replacing the growth medium with maintenance medium, containing 50 or $100 \mu \mathrm{g} / \mathrm{ml}$ of the compound. After 18 hours at $37^{\circ} \mathrm{C}$, treated and non-treated control cultures were inoculated with approximately $3 \times 10^{2} \mathrm{TCID}_{50}$ of VW 572 virus. Cultures were harvested after 3 days and titrated for infectivity.

Tests were carried out in a similar manner with transmissible gastroenteritis (TGE) virus, a known RNA-virus, and with Aujeszlky's disease virus, a known DNA-virus. These cultures were harvested after 3 and 1 days of incubation, respectively, and the infectivity titers were determined.

\subsubsection{Sensitivity to Ether, Ultraviolet Light, Heat and Acid pH}

Sensitivity to ether was tested as earlier described (27) using 20 per cent ethylether at $4^{\circ} \mathrm{C}$ for 18 hours while constantly stirring. A known ether resistant (swine enterovirus) and ether sensitive virus (TGE virus) were included as controls.

U.V. sensitivity tests were performed with $1 \mathrm{ml}$ portions of virus containing medium, layered in $6 \mathrm{~cm}$ plastic Petri dishes. Samples were irradiated with a Philips 15 Watt germicidal tube, at a distance of $30 \mathrm{~cm}$. Control samples were kept under similar conditions, but without U.V. irradiation. U.V. treated and control fluids were collected at various time intervals and the infectivity titers and hemagglutination titers were determined.

The inactivation rate of the VW 572 isolate at $37^{\circ} \mathrm{C}$ was examined by incubating vials with undiluted virus containing medium in the waterbath. At various time intervals, samples were collected and the infectivity titer was determined. The hemagglutinating activity of the sample was examined prior to the heat treatment and after complete loss of infectivity was obtained.

In order to measure viral susceptibility to acid $\mathrm{pH}$ at room temperature, virus containing medium was diluted 20 -fold in a citric acid buffer at $\mathrm{pH} 3.0$, according to the procedure described by RASMuSSEN (29). Control virus was diluted in PBS. Samples were titrated for infectious virus after various time intervals.

\subsection{Pathogenicity Studies in Experimental Pigs}

The pathogenicity of the VW572 isolate, evaluation of clinical signs, reisolation of virus and serological reactions were studied in colostrum-deprived pigs obtained by caesarean section. The pigs were reared in individual Horsfall type units, described by HaElterman (17).

Virus was administered oro-nasally to 8 pigs at the age of 5,17 or 31 days and intracerebrally to 4 pigs of 5 days old. Each pig received $10^{6.7}$ TCID $_{50}$ virus in a $1 \mathrm{ml}$ volume. Five control pigs were kept as noninfected littermates. The pigs were examined twice daily for the presence of clinical signs.

Inoculated pigs were killed at 4, 6, 9, 18 or 24 days postinoculation and several organs were collected for virus isolation. From each organ a 20 per cent suspension was prepared in PBS and further treatment for isolation of the virus was performed as described above. For virus isolation PPK cells were inoculated. If no evidence of ininfection was present either by hemadsorption and/or CPE after three serial passages, the specimen was considered to be negative for virus and further passage was discontinued.

In 2 pigs, inoculated oro-nasally at 17 days of age, virus excretion was followed by collecting nasal, pharyngeal and rectal swabs daily up to 15 days after inoculation. The swabs were submerged in $1.5 \mathrm{ml}$ of PBS. The fluids were treated with antibiotics and without further dilution tested for virus as described.

\subsection{Serologic Studies}

\subsubsection{Sera}

Sera were prepared from paired blood samples collected from each experimentally infected pig. All sera were inactivated at $56^{\circ} \mathrm{C}$ for 30 minutes and examined for hemagglutination-inhibiting and neutralizing antibodies against the VW 572 isolate. 
Identification of the VW 572 isolate was performed by hemagglutination inhibition and cross seroneutralization tests using own antisera and antisera obtained from Dr. $W$. L. Mengeling of the U.S. Department of Agriculture, Ames, Iowa, and from Miss Sheila F. Cartwright of the Central Veterinary Laboratory, Weybridge, England.

\subsubsection{Hemagglutination Inhibition (HI) and Seroneutralization (SN) Tests}

HI tests were performed using a series of twofold dilutions of serum in $0.25 \mathrm{ml}$ amounts in PBS. To each serum dilution an equal volume of virus, containing 4 HA units, was added. After incubation of the mixtures at room temperature for 1 hour, $0.25 \mathrm{ml}$ of a 0.5 per cent suspension of ehicken erythrocytes was added. Tests were read after a further 30 minutes incubation period. The HI titer was taken as the reciprocal of the highest serum dilution which caused complete inhibition of hemagglutination.

SN testing was carried out with approximately 100 TCID $_{50}$ of virus in $0.1 \mathrm{ml}$ of medium added to an equal volume of serial twofold serum dilutions in PBS. After an incubation period of 1 hour at room temperature, $0.2 \mathrm{ml}$ of each mixture was inoculated in tubes with PPK cells. The results were read on the basis of cytopathic effects; often, in order to make endpoints more clear, hemadsorbing activity of the cells was tested. Titers are recorded as the reciprocal of the highest serum dilution showing complete neutralization of virus.

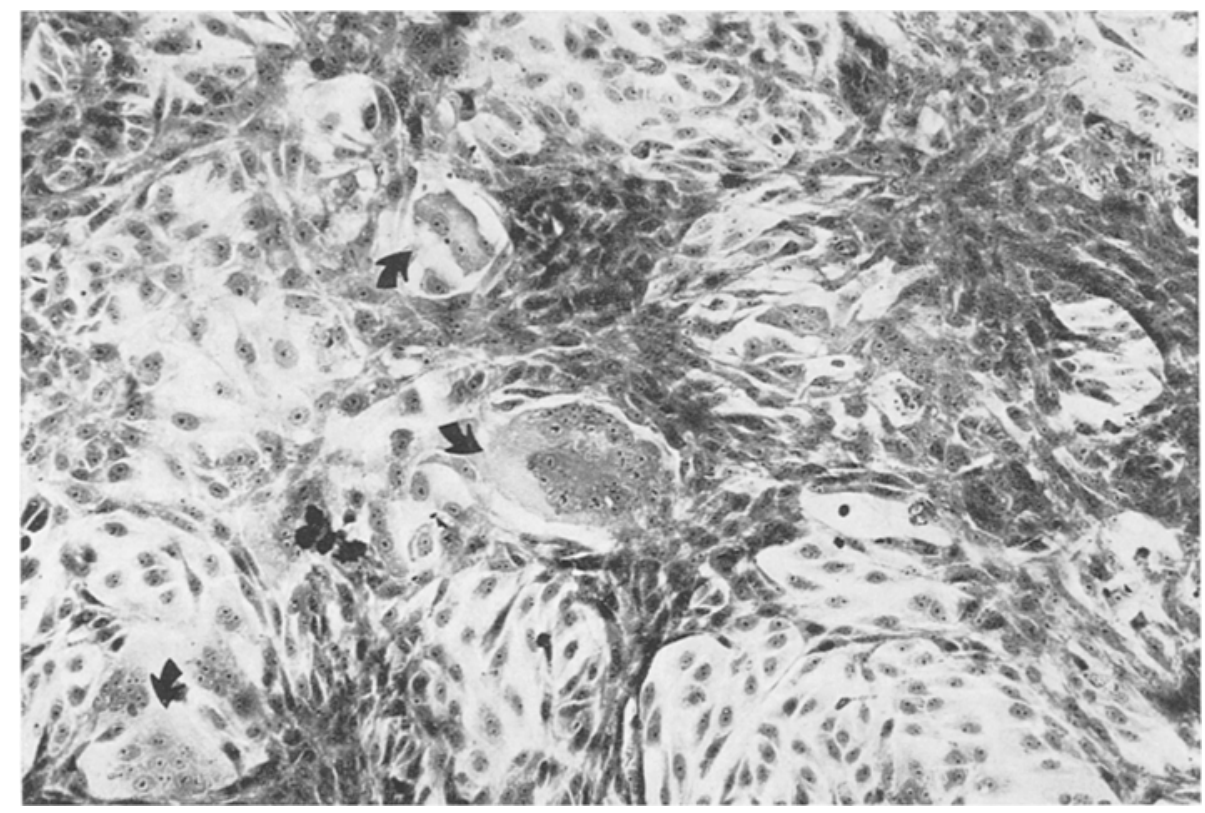

Fig. 1. Syncytia (arrows), induced by VW572 virus in primary pig kidney cell monolayers, $\amalg$ \& $\mathrm{E}$ stain, $\times 300$

\section{Results}

\subsection{Biological Characteristics of the VW 572 Isolate}

\subsubsection{Cytopathology}

In unstained PPK cell cultures, the early cytopathic effect of VW 572 virus, observed about 12 to 18 hours postinoculation, was characterized by the formation of small, almost circular, clear areas, scattered throughout the monolayer. They contained a number of oval refractile bodies, which were identified as cell nuclei after staining with $\mathrm{H} \& \mathrm{E}$ stain. $\mathrm{H} \& \mathrm{E}$ staining revealed numerous syncytia (Fig. 1) 
with usually less than 10 nuclei. Giant cells with 10 to 20 nuclei were, however, not scarce, and occasional syncytia contained up to 60 nuclei. Syncytia degenerated by contracting, forming focuses of oblonge, irregular, refractile masses in unstained cultures. These fell off the glass surface, leaving holes in the monolayer. Finally, these holes were filled up, presumably by newly formed cells, and a culture appearing relatively normal was left.

\subsubsection{Hemagglutination and Hemadsorption}

Hemagglutination with the VW572 isolate was observed with chicken, mouse and rat erythrocytes at the 3 temperatures used, but not with erythrocytes from guinea pig, rabbit, goat, sheep and pig. Turkey erythrocytes agglutinated only at $4^{\circ} \mathrm{C}$ and at room temperature.

Especially at $22^{\circ}$ and $37^{\circ} \mathrm{C}$ erythrocytes of mouse and rat were more sensitive to agglutination than chicken erythrocytes (Table 1).

\begin{tabular}{|c|c|c|c|}
\hline \multirow{2}{*}{$\begin{array}{l}\text { Erythrocyte } \\
\text { species }\end{array}$} & \multicolumn{3}{|c|}{ HA-titers ${ }^{b}$ at different temperatures } \\
\hline & $\overline{4^{\circ} \mathrm{C}}$ & $22^{\circ} \mathrm{C}$ & $37^{\circ} \mathrm{C}$ \\
\hline Chicken & 64 & 32 & 16 \\
\hline Turkey & 8 & 2 & neg. ${ }^{\circ}$ \\
\hline Rat & 128 & 256 & 128 \\
\hline Mouse & 256 & 128 & 128 \\
\hline
\end{tabular}

a Avian erythrocytes were made up as 0.25 per cent suspensions in PBS, mammalian as 0.5 per cent suspensions.

$b$ Titers are recorded as the reciprocal of the highest virus dilution causing hemagglutination.

- No hemagglutination detected with undiluted virus suspension.

The erythrocytes of all species which are agglutinated by the virus, were adsorbed to infected PPK cells at the 3 temperatures tested. At $22^{\circ} \mathrm{C}$ the attachment of erythrocytes resisted the action of two washings of the cell sheet with PBS.

\subsubsection{Growth Curve}

The growth curve of the VW572 isolate, followed by production of infectious cell-associated (CAV) and extracellular virus (ECV) and hemagglutinating (HA) activity is presented in Figure 2. Simultaneous infection of all cells in the tubes was not obtained, although the first part of the growth curve corresponds to the first cycle of replication. Following inoculation, an initial fall of virus input occurred during the first 4 hours. The production of CAV started within 6 hours. Between 6 and 12 hours, the virus titer of input was regained and maximal levels were reached from 12 to 24 hours postinoculation (PI). The growth curve of ECV followed very closely that of the $\mathrm{CAV}$ and maximal titers were reached around 24 hours PI. 
HA-titers of the cell-associated fraction increased rapidly from 6 to 12 hours PI corresponding to a rapid increase in infectivity from $10^{2.8}$ to $10^{5.1}$ TCID $_{50}$. HAtiters increased until 24 hours. No hemagglutination was detected in the cell-free virus fraction until 18 hours PI. A rapid increase was then seen between 18 hours and 24 hours. The curve of the infectivity titers and HA activity of the CAV and ECV showed a short fall at the end of the first replication cycle and than gradually declined starting at 36 hours PI.

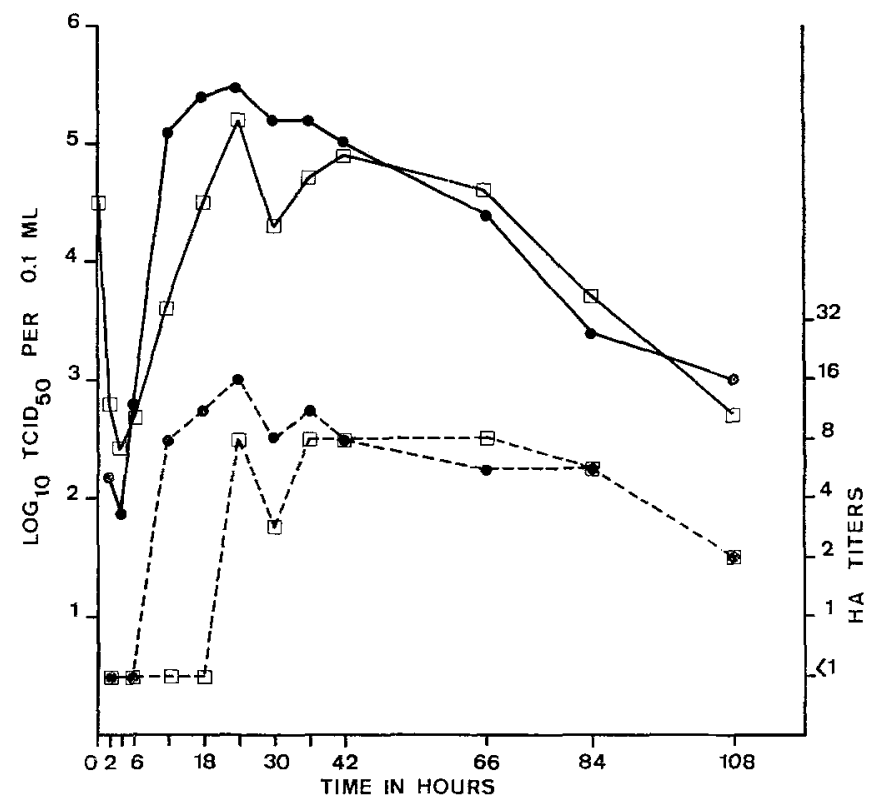

Fig. 2. Growth curves of VW 572 virus in PPK cells

- - infectivity cell-associated virus; $\square-\square-\square$ infectivity extra-cellular virus; $-\ldots--\bullet$ hemagglutinating activity cell-associated virus; $\square-\ldots-\square$ hemagglutinating activity extra-cellular virus

Adsorption of chicken erythrocytes to approximately 25 per cent of the cell sheet was observed within 12 hours PI. Between 18 and 30 hours, the number of hemadsorbing cells gradually increased up to 75 per cent and then declined. Cytopathic effect was first seen as few syncytia at 12 hours PI. At 18 hours, CPE had developed in almost 50 per cent of the monolayer but syncytia had started to fall off the glass. At 24 hours, approximately 50 per cent of the cells had detached. In the next 24 hours, the cell sheets became less affected since most holes in the monolayer disappeared.

\subsection{Physico-Chemical Properties of the VW572 Isolate}

\subsubsection{Filtration}

Viral hemagglutinin and infectivity passed through filters of 450 and $220 \mathrm{~nm}$ ADP without detectable loss. Hemagglutinating activity was completely lost in the filtrate after filtration through filters with $100 \mathrm{~nm}$ ADP, whereas in 2 trials a very 
small portion of infectious virus still remained. In one trial no infectious virus passed through the $100 \mathrm{~nm}$ ADP filter. All infectivity was removed by passage through filters of $50 \mathrm{~nm}$ ADP. The results are presented in Table 2.

Table 2. Filtration of the VW572 Isolate

\begin{tabular}{|c|c|c|c|c|c|c|}
\hline \multirow[b]{2}{*}{$\begin{array}{l}\text { Av, pore diameter } \\
\text { (nm) }\end{array}$} & \multicolumn{2}{|l|}{ Trial I } & \multicolumn{2}{|l|}{ Trial II } & \multicolumn{2}{|l|}{ Trial III } \\
\hline & $\begin{array}{l}\text { Infectivity } \\
\text { titer }\end{array}$ & $\begin{array}{l}\text { titer }^{\mathrm{b}} \\
\text { tite }\end{array}$ & $\begin{array}{l}\text { Infeetivity } \\
\text { titer }\end{array}$ & $\begin{array}{l}\mathrm{HA} \\
\text { titer }\end{array}$ & $\begin{array}{l}\text { Infeotivity } \\
\text { titer }\end{array}$ & $\begin{array}{l}\text { HA } \\
\text { titer }\end{array}$ \\
\hline unfiltered & 4.3 & 32 & 6.0 & 32 & n.t.e & 64 \\
\hline 450 & 4.5 & 32 & 5.5 & 32 & 5.5 & 64 \\
\hline 220 & 4.7 & 32 & 5.3 & 32 & 5.5 & 64 \\
\hline 100 & 0.7 & neg. d & 1.3 & neg. & neg. & neg. \\
\hline 50 & neg. ${ }^{c}$ & neg. & neg. & neg. & neg. & neg. \\
\hline
\end{tabular}

a Infectivity titers are recorded in $\log _{10}$ median tissue culture infective doses per $0.1 \mathrm{ml}$.

b HA-titers are expressed as the reciprocal of the highest dilution causing hemagglutination.

c No infectivity detected in undiluted material.

d No hemagglutination detected in the undiluted filtrate.

e Not tested.

\subsubsection{Type of Nucleic Acid}

The results of the IDU experiments are presented in Table 3 . It can be seen that IDU did not inhibit the production of infectious VW572 virus or TGE virus, whereas the infectivity titer of Aujeszky's disease virus was markedly reduced.

Table 3. Effect of 5-Lodo-2'-Deoxyuridine (IDU) on the Production of VW572 Virus and Control Viruses in PPK Cells

\begin{tabular}{|c|c|c|c|c|}
\hline \multirow[b]{2}{*}{ Triaxl } & \multirow[b]{2}{*}{ Yirus } & \multirow{2}{*}{$\begin{array}{l}\text { Concentration of } \mathrm{IDU} \\
\mu \mathrm{g} / \mathrm{ml} \text { medium }\end{array}$} & \multicolumn{2}{|c|}{ Infectivity titer ${ }^{a}$} \\
\hline & & & with IDU & without IDV \\
\hline \multirow[t]{3}{*}{ I } & VW 572 & \multirow{3}{*}{50} & 5.2 & 4.7 \\
\hline & Aujeszky & & 4.2 & 6.5 \\
\hline & TGE & & n.t. b & n.t. \\
\hline \multirow[t]{3}{*}{ II } & VW 572 & \multirow[t]{3}{*}{50} & 5.3 & 5.3 \\
\hline & Aujeszlky & & 4.5 & 7.5 \\
\hline & TGE & & 5.6 & 5.3 \\
\hline \multirow[t]{3}{*}{ III } & VW 572 & \multirow[t]{3}{*}{100} & 5.2 & 5.7 \\
\hline & Aujeszky & & 4.5 & 6.7 \\
\hline & TGE & & 5.2 & 5.2 \\
\hline \multirow[t]{3}{*}{ IV } & VW 572 & \multirow[t]{3}{*}{100} & 4.7 & 5.3 \\
\hline & Aujeszky & & 4.5 & 7.5 \\
\hline & $\mathrm{TGE}$ & & 4.7 & 5.3 \\
\hline
\end{tabular}

a Infectivity titers are recorded in $\log _{10}$ median tissue culture infective doses per $0.1 \mathrm{ml}$.

b Not tested. 


\subsubsection{Resistance to Chemical and Physical Agents}

Ether treatment during 18 hours completely destroyed the infectivity of VW572 virus and reduced the hemagglutination titer from 32 to 8 . The infectivity of TGE virus was also removed, whereas it remained unaltered with the swine enterovirus.

The rate of inactivation of VW572 infectivity and hemagglutinating activity by ultraviolet irradiation is shown in Figure $3 \mathrm{~A}$ and $3 \mathrm{~B}$. The inactivation curve of viral infectivity (Fig. 3A) consisted of two parts, the slope of the first being about nine times steeper than the second. Extrapolation of the second part to zero U.V. dose gave a $N / N_{0}$ value of about $10^{-4.3}$. The hemagglutination titer (Fig. $3 \mathrm{~B}$ ) gradually increased by irradiation with $\mathrm{U}$.V. light and reached a maximal value of twice the original one after irradiation for 7 to 20 minutes. At 30 minutes of irradiation, the hemagglutinating activity started to fall; it was completely lost after 90 minutes of U.V. irradiation.
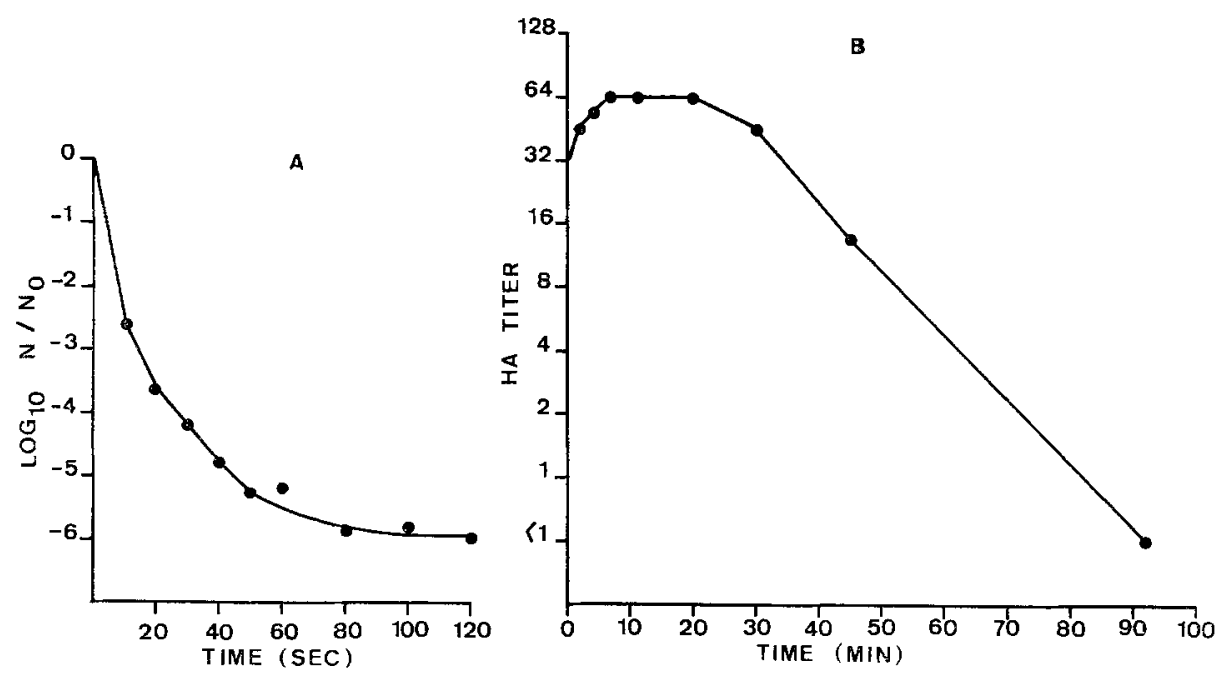

Tig. 3. The inactivation of infectivity (A) and hemagglutinating activity (B) of VW 572 virus by ultraviolet light irradiation. $\mathrm{N}_{0}=$ infectivity titer prior to $\mathrm{U}$.V. irradiation; $\mathrm{N}=$ infectivity titer after U.V. irradiation. HA-titer is recorded as the reciprocal of the maximal dilution causing hemagglutination

The curve, showing the decrease in viral infectivity at $\mathrm{pH} 3.0$ and at room temperature during a period of 24 hours (Fig. 4), also consisted of 2 branches; the slope of the first was almost 15 times steeper than that of the second and by extrapolating the second branch to zero time an average $\mathrm{N} / \mathrm{N}_{0}$ value of about $10^{-1.6}$ was read.

The inactivation curve of viral infectivity at $37^{\circ} \mathrm{C}$ is shown in Figure 5 . Starting from an infectivity titer of $10^{6.0}$ TCID $_{50}$ per $0.1 \mathrm{ml}$ at zero time, infectivity progressively decreased and was completely lost after 72 hours. By that time, the hemagglutination titer had decreased from 128 to 32 but was not completely lost. 


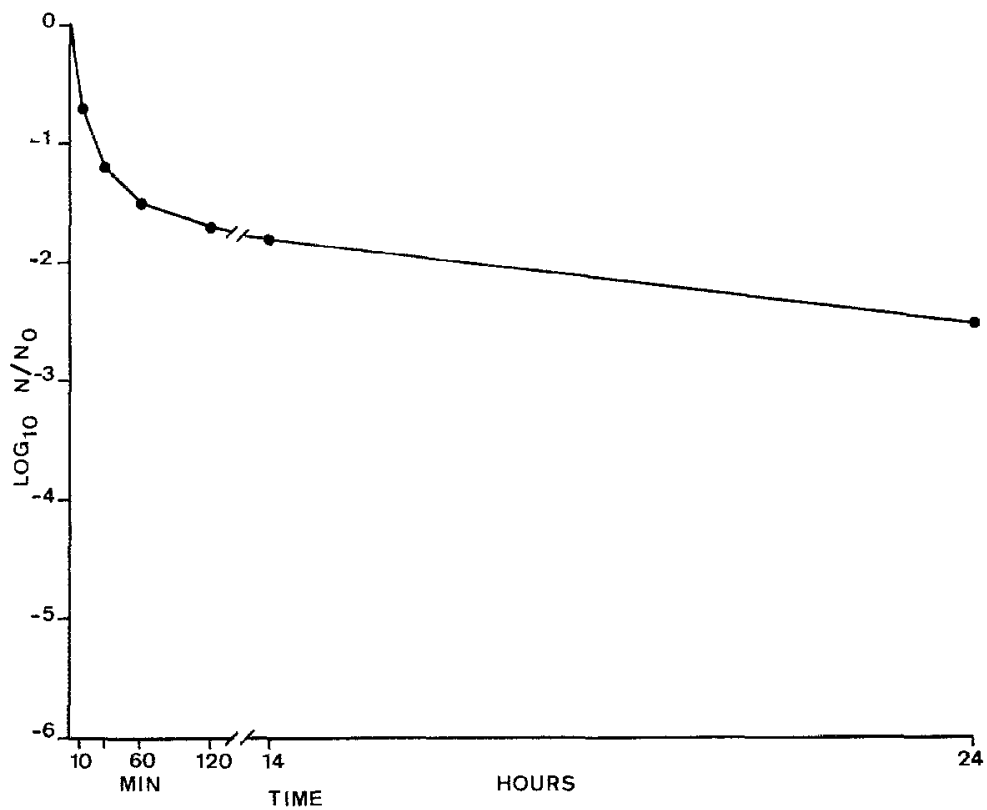

Fig. 4. Sensitivity of $\mathrm{VW} 572$ infectivity to $\mathrm{pH} 3.0$ at room temperature. $\mathrm{N}_{0}=$ infectivity titer prior to pH treatment; $\mathrm{N}=$ infectivity titer after $\mathrm{pH}$ treatment

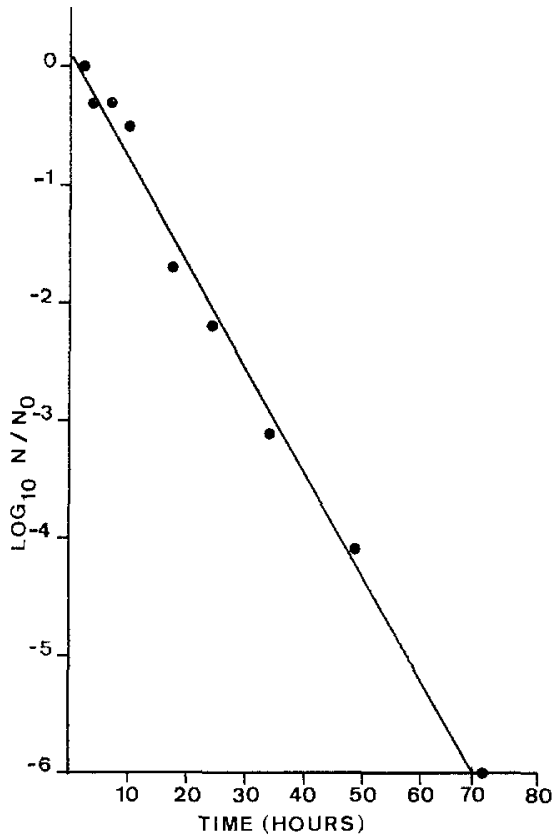

Fig. s. The inactivation of VW 572 infectivity at $37^{\circ} \mathrm{C} . \mathrm{N}_{0}=$ infectivity titer prior to treatment; $\mathbf{N}=$ infectivity titer after treatment 


\subsection{Pig Experiments}

\subsubsection{Clinical Disease}

Pigs inoculated oro-nasally showed clinical signs after an incubation period of 5 to 6 days. They became markedly depressed and frequently vomited. The pigs appeared to have little appetence. Soon after the uptake of milk started, it was discontinued and vomition occurred. The frequency of vomition somewhat decreased after 2 to 3 days but the pigs remained depressed. Pigs inoculated at 5 days of age became very weak about 4 days after the appearance of clinical signs. In one of them, a slight tremor was observed.

The pigs inoculated at $\mathbf{1 7}$ days of age showed similar clinical signs but became chronically affected. Their milk uptake was markedly reduced, vomition regularly occurred and they did not gain weight. After 2 to 3 weeks, the pigs became very thin and their abdomen was distended. Only one of the pigs inoculated at the age of one month became clinically ill whereas the other remained healthy. None of the control pigs became sick.

Four pigs, inoculated intracerebrally, showed clinical signs after an incubation period of 4 days. The clinical disease was characterized by marked depression, loss of appetence, vomition, weakness after 4 to 5 days. Obvious central nervous disorders as ataxia, incoordination or paralysis were not seen in any of the pigs.

\subsubsection{Virus Excretion and -Isolation from Organs}

In the oro-nasally inoculated pigs, virus was detected in nasal swabs from 2 to 8 days after inoculation. In pharyngeal swabs, virus could be isolated from the first day up to 6 days after inoculation. Virus was not detectable in rectal swabs. In pigs inoculated oro-nasally and killed at different time intervals thereafter, virus was isolated from nasal mucosa, tonsils, lung and brain stem but not from the salivary gland, stomach, intestine, cerebrum or cerebellum. In pigs killed after intracerebral inoculation, virus could be detected in the same organs and also in the cerebrum and cerebellum. The results of the virus isolation from different organs of pigs inoculated oro-nasally and intracerebrally with the VW572 isolate and killed at different time intervals are presented in Table 4.

\subsubsection{Serological Reaction of Experimental Pigs}

The hemagglutination-inhibition (HI) titers and seroneutralization (SN) titers of the sera collected from the experimentally inoculated pigs at the time of necropsy are presented in Table 4 . HI-antibodies against the VW572 isolate were demonstrable as soon as 6 days after inoculation whereas SN-antibodies were first detectable at 9 days postinoculation. All presera were found to be free of antibodies against the VW572 isolate (HI-titer $<2 ; \mathrm{SN}$-titer $<5$ ).

\subsection{Identification of the $V W 572$ Isolate}

With both the HI-test and SN-test, antigenic relationship could be demonstrated by allowing the present VW572 isolate to react with sera against the HEV isolate from Mengeling and the VWD isolate from Cartwright. Titers obtained during these identification studies are presented in Table 5 . 
Table 4. Virusisolation and Serological Reaction in Experimental Pigs Inoculated with VW572 Virus

\begin{tabular}{|c|c|c|c|c|c|c|c|c|c|c|c|c|c|c|}
\hline \multirow{3}{*}{$\begin{array}{l}\text { Way of } \\
\text { inoculation }\end{array}$} & \multirow{3}{*}{$\begin{array}{l}\text { Pig } \\
\text { no. }\end{array}$} & \multirow{3}{*}{$\begin{array}{l}\text { Age at } \\
\text { inoculation } \\
\text { (days) }\end{array}$} & \multirow{3}{*}{$\begin{array}{l}\text { Killed } \\
\text { after } \\
\text { inocul. } \\
\text { (days) }\end{array}$} & \multicolumn{9}{|c|}{ Virusisolation } & \multirow{2}{*}{\multicolumn{2}{|c|}{$\begin{array}{l}\text { Serological examination } \\
\text { at necropsy }\end{array}$}} \\
\hline & & & & \multirow{2}{*}{ 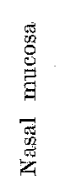 } & \multirow{2}{*}{ 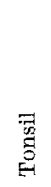 } & \multirow{2}{*}{ 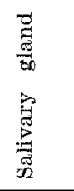 } & \multirow{2}{*}{ 驾 } & \multirow{2}{*}{$\begin{array}{l}\Xi \\
\text { E. } \\
0 \\
0 \\
0 \\
0\end{array}$} & \multirow{2}{*}{ 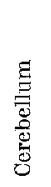 } & \multirow{2}{*}{ 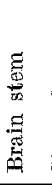 } & \multirow{2}{*}{ 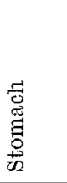 } & \multirow{2}{*}{ 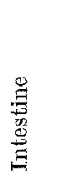 } & & \\
\hline & & & & & & & & & & & & & HI-titer ${ }^{2}$ & SN-titer b \\
\hline oro- & 1 & 5 & 6 & + & + & - & + & - & - & + & n.t. & - & 4 & $<5$ \\
\hline \multirow[t]{8}{*}{ nasally } & 2 & 5 & 6 & - & $\div$ & - & + & - & - & + & n.t. & n.t. & 4 & $<5$ \\
\hline & 3 & 5 & 9 & - & - & - & - & - & - & - & - & - & 256 & 320 \\
\hline & 4 & 5 & 9 & - & - & - & - & - & - & - & n.t. & - & 128 & 80 \\
\hline & 5 & 17 & 24 & n.t. & $c_{-}-1$ & n.t. & - & - & - & - & - & - & 128 & 80 \\
\hline & 6 & 17 & 24 & n.t. & -1 & n.t. & - & - & - & - & - & - & 256 & 80 \\
\hline & 7 & 31 & 18 & - & -1 & n.t. & - & - & - & - & - & - & 256 & 160 \\
\hline & 8 & control & & - & - & - & - & - & - & - & - & - & $<2$ & $<5$ \\
\hline & 9 & control & & - & - & - & - & - & - & - & - & - & $<2$ & $<5$ \\
\hline intra- & 10 & 5 & 4 & n.t. & +1 & n.t. & $\div$ & + & + & + & - & - & n.t. & n.t. \\
\hline \multirow[t]{3}{*}{ cerebral. } & 11 & 5 & 4 & n.t. & +1 & n.t. & + & + & - & + & - & - & n.t. & n.t. \\
\hline & 12 & $\check{5}$ & 6 & + & + & - & + & + & + & + & - & - & 8 & n.t. \\
\hline & 13 & $\check{5}$ & 6 & + & + & - & + & + & + & - & - & - & 32 & n.t. \\
\hline
\end{tabular}

a The HI-titers are expressed as the reciprocal of the highest serumdilution causing complete inhibition of hemagglutination (4 HA units).

b The SN-titers are expressed as the reciprocal of the highest serumdilution causing complete neutralization $\left(100 \mathrm{TCID}_{50}\right)$.

c Not tested.

Table 5. Titers of Antisera to HEV in Cross Seroneutralization and HemagglutinationInhibition Tests with VW 572 Isolate

\begin{tabular}{|c|c|c|c|c|}
\hline \multirow[b]{2}{*}{ Antiserum to } & \multicolumn{2}{|c|}{ Titers of preserum } & \multicolumn{2}{|c|}{ Titers of postserum } \\
\hline & $\mathrm{HI}^{\mathrm{a}}$ & $\mathrm{SN}^{\mathrm{a}}$ & $\mathrm{HI}$ & $\mathrm{SN}$ \\
\hline \multicolumn{5}{|l|}{ HEV' (MENGELING) } \\
\hline sample 1 & $<5$ & $<5$ & 640 & 240 \\
\hline sample 2 & $<5$ & $<5$ & 640 & 160 \\
\hline sample 3 & n.a.d & n.a. & 640 & 480 \\
\hline VWD ${ }^{\circ}$ (CARTWRIGHT) & n.a. & n.a. & 4096 & 5120 \\
\hline
\end{tabular}

a Hemagglutination-inhibition and seroneutralization titers are expressed as the reciprocal of the highest dilution causing complete inhibition of hemagglutination and loss of infectivity respectively.

b HEV : hemagglutinating encephalitis virus.

c VWD: vomiting and wasting disease.

d Not available.

\section{Diseussion}

By filtration through filters of graded porosity, the size of virions of VW572 is situated between 100 and $220 \mathrm{~nm}$. However, the ability of some virus to pass a filter of $100 \mathrm{~nm}$ ADP suggests the presence of a small fraction of infectious particles with dimensions between 100 and $50 \mathrm{~nm}$. The results of our filtration 
studies show the hemagglutinin to be associated with structures of the same size range as that of infective particles, presumably with the virion.

The presence of a halogenated deoxyuridine, at concentrations markedly inhibiting the multiplication of a control DNA virus, has no inhibitory effect on the VW572 reproduction. This indicates that the VW572 nucleic acid is of the RNA-type. The size, nucleic acid type, ether sensivity and further characteristios such as the formation of syncytia, hemagglutinating and hemadsorbing activity, association of hemagglutinin with the virion, indicate the similarity of the VW572 isolate with hemagglutinating encephalitis virus $(\mathrm{HEV})(11,12,13,16)$, vomiting and wasting disease (VWD) virus $(5,6)$ and $\mathrm{HEV} 67 \mathrm{~N}(22,24)$, isolated in Canada, England and the U.S.A., respectively, for which the classification as a coronavirus was already proposed $(15,22,28)$. The present results with the VW572 isolate are in agreement with such classification.

The U.V. dose, inactivating the VW 572 infectivity is comparable to that found by GREIG and BoullLANT for HEV (16). The U.V. inactivation curve of VW572 infectivity points to a "double hit" curve, and indicates that the viruses are not aggregated into clumps, as was reported for human coronaviruses strains $229 \mathrm{E}$ and $\mathrm{OC} 43$ (3). The reason for the present heterogeneity in U.V. sensitivity of the viral infectivity is not known. The temporary increase in HA-titer with VW572 after U.V. irradiation has not been reported previously for this virus. A similar observation was made with influenza virus (9).

The range of erythrocytes agglutinated by VW572 virus and adsorbed to VW 572 infected PPK cells corresponds to that reported by MENGELING et al. (22), but differs from the range found by GIRARD et al. (8) in that neither rabbit nor sheep cells are agglutinated by VW572. Direct hemagglutination (i.e. without pretreatment of the virus) and hemadsorption have been described for a human coronavirus, strain OC43 $(19,20)$. The host range of agglutinated and adsorbed erythrocytes as well as gradation in sensitivity and optimal temperature for agglutination of tested erythrocytes with the $\mathrm{OC} 43$ strain are similar to the results obtained with the VW572 hemagglutination and hemadsorption experiments. On the other hand, since hemadsorption kept stable after twofold washing of the adsorbing cell sheet, it is thought not to be a "pseudohemadsorption", due to accumulation of newly formed virus particles at the external cell surface, as described by BUCKNALL et al. (4). The occurrence of hemadsorption may be an indication for an altered structure of the cell membrane, as proposed by MENGeLrng et al. (22).

Although PHumIP et al. reported that the VWD virus was relatively acid stable (28), the major fraction of the VW572 virus population appears to be inactivated after approximately 2 hours at pH 3 . A small fraction of about 2.5 per cent of the VW572 isolate is acid-stable for over 24 hours. Acid-lability has been described. for avian, murine and human coronaviruses (2), whereas a porcine coronavirus TGE (33), has been reported to be relatively acid-stable (28). The heterogeneity to acid $\mathrm{pH}$ within the $\mathrm{VW} 572$ isolate is unknown, although a similar phenomenon has been described for most populations of foot-and-mouth disease virus (18).

Growth curve experiments indicate that one growth cycle is completed within 24 hours. The presence of hemagglutinating activity associated with the production of cell-associated infectious virus suggests that the viral maturation process occurs very quickly. The pattern of increase of the cell-free virus follows approxi- 
mately that of the cell-associated virus which suggests a rapid release of intracellularly produced virus. At 66 hours the curve falls at a rate comparable to the inactivation rate of viral infectivity at $37^{\circ} \mathrm{C}$; by that time the newly synthesized cells in the monolayer presumably no longer support virus growth.

The clinical disease obtained by inoculation of colostrum-deprived pigs with the VW572 isolate resembles very much the disease seen in the field and the clinical picture described in several European countries $(5,10,31,32)$. It also resembles the description given by MENGELINQ in pathogenicity tests with the $\mathrm{N} 67$ isolate of $\mathrm{HEV}$ (23). However, no respiratory signs or constipation, as described by Mengeling (23) and Cartwright (5) were observed. The present isolate appeared to be quite virulent for pigs up to one month of age since all inoculated animals, except one, became typically ill. The mortality rate could not be examined in the present work since all pigs were killed for further examination prior to death. From field cases, however, it can be said that practically all affected young pigs eventually die whereas older pigs with clinical signs remain unproductive. The clinical disease described with the VW572 isolate is different from most of the Canadian descriptions of hemagglutinating encephalitis in which acute signs of encephalitis are mainly observed $(1,11)$. Mitchels, however, reported outbrealks in Canada with signs of vomition and wasting in older pigs (26). During serological examination of several Canadian HEV isolates, GREIG et al. (14) found one isolate to be somewhat different from the others. It is, therefore, possible that at least two variants of HEV exist with some difference in pathogenicity pattern.

In identification studies, the VW572 isolate was tested only against sera prepared against the American and the British isolate both of which cause the vomiting disease and no antigenic differences could be found by hemagglutination inhibition and seroneutralization test. Although antigenic relationship with the Canadian isolates was not examined, MENGELING using the seroneutralization and hemagglutination inhibition tests (25) and CARTwRIGHT using the hemagglutination inhibition test (5) reported their isolates to be antigenically related to a Canadian isolate.

The present results with the VW572 isolate in which virus could be isolated from experimentally infected pigs not longer than 8 days after inoculation are in agreement with earlier observations $(6,7)$. Many attempts to make a diagnosis by virus isolation from chronically affected pigs in field outbreaks have, therefore, failed.

Concurrent serological examination showed that virus isolation was possible in the presence of a low titer of hemagglutination inhibition antibodies but became impossible as soon as neutralizing antibodies were demonstrable. The presence of these antibodies apparently prevents further isolation of cell-free virus.

Although the pathogenesis of vomiting and wasting disease was not studied in the present work, the oral or nasal uptake of the virus seems to be the natural way of entrance in pigs. The ability to isolate virus regularly in nasal and pharyngeal swabs and the successful isolation from nasal mucosa, tonsils and lungs suggested the primary replication in one of these tissues.

Virus is excreted and transmitted mainly if not only by nasal excretions. The presence of virus in the brain stem after oro-nasal inoculation and the ability to 
produce typical disease after a shorter incubation period upon intracerebral inoculation suggests that the clinical signs of vomition and wasting are centrally induced. The inability to isolate virus from the gastrointestinal tract and from fecal swabs, even though the gastrointestinal function is mainly disturbed, seems to indicate that this organ is not primaily affected by the virus.

The pathogenesis of vomiting and wasting disease with relation to the exact mechanism of action of the virus and the origin of the functional disorders in the gastrointestinal tract needs to be further examined.

\section{Acknowledgments}

The study was supported by the Belgian Research Institute for Industry and Agriculture (IWONL), Brussels, Belgium. We would like to thank Miss Cartwright, Weybridge, England and Dr. Mengeling, U.S.A., for providing specific antisera against their isolates.

The technical assistance of Gerry Van Leeuwe and Lut Wolfs is gratefully acknowl edged.

\section{References}

1. Alexander, T. J. L., E. P. C. Richards, and C. K. Rog: An encephalomyelitis of suckling pigs in Ontario. Canad. J. comp. Med. 23, 316-319 (1959).

2. Bradburne, A. F., and D. A. J. Tyrrell: Coronaviruses of man. Progr. med. Virol. 13, 373-403 (1971).

3. Bucknali, R. A., L. M. King, A. Z. Kaptkian, and R. M. Chanock: Studies with human coronaviruses. Proc. Soc. exp. Biol. (N.Y.) 139, $722-727$ (1972).

4. Bucknall, R. A., A. R. Katica, and R. M. Chanock: Intracellular development and mechanism of hemadsorption of a human coronavirus OC 43. Proc. Soc. exp. Biol. (N.Y.) 139, 811-817 (1972).

5. Cartwrighr, Sheila F., M. Lucas, J. P. Cavill, A. F. Gush, and T. B. BlandFORD : Vomiting and wasting disease of piglets. Vet. Rec. 84, 175-176 (1969).

6. CARTwright, Sheila F., and M. Lucas: Vomiting and wasting disease in piglets. Vet. Rec. 86, 278-280 (1970).

7. Cutlip, R. C., and W.L. Mengeling: Lesions induced by hemagglutinating encephalomyelitis virus strain $67 \mathrm{~N}$ in pigs. Amer. J. vet. Res. 33, 2003-2009(1972).

8. Girard, A., A. S. Greitg, and D. Mitchell: Encephalomyelitis of swine caused by a hemagglutinating virus. III. Serological studies. Res. vet. Sci. 5, $294-302$ (1964).

9. Goldostein, M. A., and N. M. Tauraso: Effect of formalin, B-propiolactone, merthiolate and ultraviolet light upon influenza virus infectivity, chicken cell agglutination, hemagglutination and antigenicity. Appl. Microbiol. 19, 290-294 (1970).

10. Gotink, W. M., G. M. Lambers, H. van Soest, and F. W. van Ulsen: Vomiting and wasting disease in piglets. Vet. Rec. 84, 445-446 (1969).

11. Greig, A. S., D. Mrtcheld, A. H. Corner, G. L. Bannister, E. B. Meads, and R. J. Jutrax: A hemagglutinating virus producing encephalomyelitis in baby pigs. Canad. J. comp. Med. 26, 49-56 (1962).

12. GREIG, A. S., and A. GIRARD : Encephalomyelitis of swine caused by a hemagglutinating virus. II. Virological studies. Res. vet. Sci. 4, $511-517$ (1963).

13. GREIG, A. S., and A. Girard : Encephalomyelitis of swine caused by a hemagglutinating virus. $V$. Response to metabolic inhibitors and other chemical compounds. Res. vet. Sci. 10, 509-513 (1969).

14. GREIG, A. S., and A. GIRARD : Serological comparison of hemagglutinating encephalomyelitis viruses isolated from different outbreaks. Canad. J. comp. Med. 33, $25-28$ (1969). 
15. Greig, A. S., M. C. Jomnson, and A. M. P. Boulluant: Encephalomyelitis of swine caused by a hemagglutinating virus. VI. Morphology of the virus. Res. vet. Sci. 12, 305-307 (1971).

16. GReig, A. S., and A. M. P. Bouillant: Studies on the hemagglutination phenomenon of hemagglutinating encephalomyelitis virus (HEV) of pigs. Canad. J. comp. Med. 36, 366-370 (1972).

17. Haelterman, E. O.: Practical isolation equipment for baby pigs. Amer. J. vet. Res. 17, 129-131 (1956).

18. Hyslop, N. St. G.: The epizootiology and epidemiology of foot and mouth disease. Advane. vet. Sei. comp. Med. 14, 261-307 (1970).

19. KaptKtan, A.Z., H. D. JaMES, JR., S. J. KeLLY, L. M. KING, A. L. VAUGH, and R. M. Chanock: Hemadsorption by coronavirus strain OC 43. Proc. Soc. exp. Biol. (N.Y.) 139, 179-186 (1972).

20. KAYE, H.S., and W.R. DowDLE: Some characteristies of hemagglutination of certain strains of "IBV-like" virus. J. infect. Dis. 120, 576-581 (1969).

21. Lennette, E. H., and Nathalie J. Schmidt: Diagnostic Procedures for Viral and Rickettsial Diseases, 4th Ed., p. 90. Amer. publ. Hlth Ass. 1969.

22. Mengeling, W. L., A. D. Boothe, and A. E. Ritchue: Characteristics of a coronavirus (strain $67 \mathrm{~N}$ ) of pigs. Amer. J. vet. Res. 32, 297-308 (1972).

23. Mengeling, W. L., and R. C. Cutuip: Experimentally induced infection of newborn pigs with hemagglutinating encephalomyelitis virus strain $67 \mathrm{~N}$. Amer. J. vet. Res. 33, 953--956 (1972).

24. Mengening, W. L., and M. F. Coria : Buoyant density of hemagglutinating encephalomyelitis virus of swine: comparison with avian infectious bronchitis virus. Amer. J. vet. Res. 33, $1359-1363$ (1972).

25. Mrengeling, W. L.: Personal communication (1973).

26. Mitcheld, D.: Encephalomyelitis of swine caused by a hemagglutinating virus. Res. vet. Sei. 4, 506-510 (1963).

27. Pensaert, M. B., T. Bupnstern, and E. O. Hafiterman : Cell culture-adapted SH strain of transmissible gastroenteritis virus of pigs: in vivo and in vitro studies. Amer. J. vet. Res. 31, 771-781 (1970).

28. Phirtip, J. I. H., Shema F. Cartwright, and A. C. Scott : The size and morphology of TGE and vomiting and wasting disease viruses of pigs. Vet. Rec. 88, 311--312 (1971).

29. Rasmussen, P. G.: A study of enterovirus strains in Danish pigs. Nord. Vet.-Med. 21, 177-187 (1969).

30. ReED, L. J., and H. Muench: A simple method of estimating fifty per cent endpoints. Amer. J. Hyg. 27, $493-497$ (1938).

31. Schlifinstedt, D., H. Barnikol und H. Plonait: Erbrechen und Kümmern bei Saugferkeln. Dtsch. tierärztl. Wschr. 76, 681-704 (1969).

32. SteInICKe, O., and A. NIELSEN : Baby pig mortality and infantile pyloric stenosis. Acta paediat. (Uppsala) 45, 444-448 (1956).

33. TaJima, M.: Morphology of transmissible gastroenteritis virus of pigs, a possible member of coronaviruses. Arch. ges. Virusforsch. 29, 105-108 (1970).

34. Ver, B. A., J. L. MELnick, and C. WALLIS: Efficient filtration and sizing of viruses with membrane filters. J. Virol. 2, 21-25 (1968).

Authors' address: Dr. M. Pensaent, Faculty of Veterinary Medicine, Laboratory of Virology, University of Ghent, Casinoplein, 24, B-9000 Ghent, Belgium. 